\title{
Puna-apilasäilörehun korjuuajan vaikutus maidontuotantoon
}

\author{
Pirjo Pursiainen ${ }^{1)}$, Mikko Tuori ${ }^{2)}$, Kaisa Kuoppala ${ }^{2)}$, Marketta Rinne ${ }^{2)}$, Pekka Huhtanen ${ }^{2)}$, ja Aila \\ Vanhatalo ${ }^{1)}$ \\ ${ }^{1)}$ Kotieläintieteen laitos, PL 28, 00014 Helsingin yliopisto, etunimi.sukunimi@helsinki.fi, ${ }^{2)}$ MTT, \\ Eläinravitsemus, 31600 Jokioinen, etunimi.sukunimi@mtt.fi
}

\section{Tiivistelmä}

Tutkimuksessa selvitettiin puna-apilasäilörehun korjuuajan vaikutusta rehun syöntiin, sulavuuteen, maidontuotantoon ja maidon koostumukseen. Puna-apilarehut säilöttiin ensikasvun aikaisesta (AA) ja myöhäisestä (AM) kehitysvaiheesta sekä niiden jälkikasvuista (AAJ ja AMJ, vastaavasti). Kontrollina oli timotei-nurminatakasvustosta aikaisessa (TNA) ja myöhäisessä (TNM) kehitysvaiheessa tehty säilörehu. Kaikki rehut oli säilötty pyöröpaaleihin AIV2Plus-säilöntäainetta käyttäen. Tutkimus tehtiin Viikin opetus- ja tutkimustilan navetassa. Tutkimuksessa oli mukana 12 ay-lehmää, jotka jaettiin tuotoksen mukaan kahteen blokkiin (2 kertaa poikineet ja ensikot). Viljan ja rypsin seosta (raakavalk. $193 \mathrm{~g} / \mathrm{kg} \mathrm{KA}$ ) annettiin 10,5 (blokki 1) tai 8,4 kg/pv (blokki 2). Säilörehua lehmät saivat vapaasti. Apilasäilörehujen kuiva-ainepitoisuus oli sateisen kesän hankalista säilöntäolosuhteista johtuen pienempi kuin heinäkasvisäilörehujen (180 (AA), 224 (AM), 251 (AAJ), 219 (AMJ), 321 (TNA) ja 277 (TNM) g/kg). Apilarehuissa oli enemmän raakavalkuaista (166, 165, 170, 193, 112 ja 90 g/kg KA, vastaavasti) ja vähemmän solunseinäkuitua (NDF) $(395,391,373,348,541$ ja 601 g/kg KA, vastaavasti) kuin heinäkasvirehuissa. Apilarehut olivat pidemmälle käyneitä ja sisälsivät vähemmän sokeria kuin heinäkasvirehut.

Sulavaa orgaanista ainetta (määritetty in vivo) säilörehuissa oli 639 (AA), 591 (AM), 619 (AAJ), 651 (AMJ), 696 (TNA) ja 619 (TNM) g/kg KA (p<0,001). Lehmät söivät eniten varhain korjattua heinäkasvisäilörehua (10,7 (AA), 9,0 (AM), 12,8 (AAJ), 11,8 (AMJ), 14,3 (TNA) ja 8,3 (TNM) $\mathrm{kg} \mathrm{KA} / \mathrm{pv}$ (p<0,001). Apilan jälkikasvusta tehtyä rehua lehmät söivät enemmän kuin apilan ensikasvusta tehtyä rehua (p<0,001). Maitotuotos oli 28,3 (AA), 28,4 (AM), 29,1 (AAJ), 29,7 (AMJ), 28,6 (TNA) ja 25,5 (TNM) kg/pv (p<0,001). Apilan jälkikasvurehuja syöneet lehmät lypsivät enemmän $(\mathrm{p}<0,05)$ kuin ensikasvurehuja syöneet lehmät. Maidon rasvapitoisuuteen ja rasvatuotokseen ruokinta ei vaikuttanut merkitsevästi. Maidon valkuaispitoisuus (33,6 (AA), 33,9 (AM), 34,8 (AAJ), 34,0 (AMJ), 35,1 (TNA) ja 34,9 (TNM) g/kg (p<0,01)) oli heinäkasviruokinnoilla suurempi kuin apilaruokinnoilla $(\mathrm{p}<0,001)$. Apilan jälkikasvusta tehtyjä rehuja syöneiden lehmien maidon valkuaispitoisuus $(\mathrm{p}<0,05)$ ja valkuaistuotos $(\mathrm{p}<0,01)$ olivat suuremmat kuin ensikasvusta tehtyjä rehuja syöneiden lehmien. Apilasäilörehu nosti maidon ureapitoisuutta heinäkasvirehuun verrattuna $(\mathrm{p}<0,001)$.

Syönnin vertailua vaikeuttivat apila- ja heinäkasvirehujen välillä säilönnällisessä laadussa olleet erot. Apilarehujen välillä tätä eroa ei ollut, mutta lehmät söivät enemmän apilan jälki- kuin ensikasvusta tehtyjä rehuja. Apilarehun korjuuajan vaikutus säilörehun syöntiin poikkeaa heinäkasvirehusta. Apilan jälkikasvurehuja verrattessa syönti lisääntyi sulavuuden pienentymisestä huolimatta. Apilaa syöneet lehmät tuottivat kuitenkin saman verran maitoa kuin aikaisin korjattua heinäkasvirehua syöneet lehmät, vaikka söivät vähemmän säilörehua.

Asiasanat: säilörehu, timotei, nurminata, puna-apila, lypsylehmä, ruokinta 


\section{Johdanto}

Heinäkasvisäilörehun korjuuajankohta vaikuttaa ratkaisevasti säilörehun sulavuuteen, syöntiin ja rehuarvoon ja siten myös väkirehutäydennyksen tarpeeseen ja laatuun lypsylehmän ruokinnassa. Varhaisessa kehitysvaiheessa korjattua, hyvin sulavaa heinäkasvisäilörehua syötettäessä väkirehun määrää lehmän ruokinnassa voidaan vähentää (Kuoppala ym. 2004). Apilan kehitysrytmi ja kemiallinen koostumus eroavat heinäkasveista, joten heinäkasvisäilörehuilla tehdyissä tutkimuksissa saatuja tuloksia ei voi suoraan soveltaa apilaa sisältävästä kasvustosta tai puhtaasta apilasta tehtyyn säilörehuun. Tämän tutkimuksen tarkoituksena oli selvittää puna-apilasäilörehun korjuuajankohdan vaikutusta lypsylehmien rehun syöntiin, dieetin sulavuuteen, maidontuotantoon ja maidon koostumukseen käytettäessä luomuruokintaan soveltuvaa matalaa väkirehun annostustasoa.

Tutkimus kuuluu MMM:n rahoittaman Luomututkimusohjelman projektiin "Puna-apila tehokkaasti luomumaidoksi”, johon saatiin myös Huoltovarmuuskeskuksen rahoitustukea.

\section{Aineisto ja menetelmät}

Apilarehut säilöttiin kesällä 2004 Viikin opetus- ja tutkimustilan n. 2,5 hehtaarin punaapilakasvustosta (lajike Varte), joka oli perustettu keväällä 2003 suojaviljaan (vehnä). Apilaa ei lannoitettu. Apilarehut säilöttiin ensikasvun aikaisesta (AA) ja myöhäisestä (AM) kehitysvaiheesta sekä näiden jälkikasvuista (AAJ ja AMJ, vastaavasti) (taulukko 1). Kontrollirehuiksi säilöttiin ensisadon timotei-nurminatakasvustoa sekä aikaisessa (TNA) että myöhäisessä kehitysvaiheessa (TNM). Kaikki rehut säilöttiin pyöröpaaleihin AIV2Plus-säilöntäainetta (5 l/tn) käyttäen.

Tutkimus tehtiin Viikin opetus- ja tutkimustilan navetassa 12 ay-lehmällä cyclic change overkokeena, jossa oli neljä 3 viikon mittaista jaksoa. Lehmät lehmät jaettiin tuotoksen mukaan kahteen blokkiin (kaksi kertaa poikineet ja ensikot). Kokeen alkaessa blokin 1 lehmien maitotuotos oli keskimäärin 40,1 (s.d. 5,0) kg päivässä ja blokin 2 lehmien 28,6 (s.d. 2,4) kg päivässä. Blokin 1 lehmillä oli aikaa poikimisesta 47-114 pv ja blokin 2 lehmillä 75-119 pv. Lehmät saivat säilörehua vapaasti. Säilörehua jaettiin kolme kertaa päivässä. Väkirehuna oli ohran ja kauran (50:50) sekä rypsin (23.8 \% väkirehun määrästä) seos, jota annettiin 10,5 (blokki 1) tai 8,4 kg/pv (blokki 2). Koska apilassa on runsaasti kalsiumia, täydennettiin apilasäilörehuja syöneiden lehmien väkirehuannosta hyvin niukasti kalsiumia sisältävällä Tarmo-kivennäisrehulla (Ca 3, P 5, Mg 65, Na 65 g/kg) (Melica Finland). Heinäkasvisäilörehuja syöneet lehmät saivat kivennäislisänä Lypsy-Melliä (Ca 114, P 31, $\mathrm{Mg}$ 56, Na $71 \mathrm{~g} / \mathrm{kg}$ ) (Rehuraisio Oy) ja ruokintakalkkia. Lisäksi kaikki lehmät saivat ruokasuolaa 50 g/pv. Väkirehu jaettiin kuudessa yhtä suuressa erässä. Rehut ja rehujätteet punnittiin päivittäin. Maitotuotos mitattiin päivittäin (Tru-Test FV). Kunkin jakson viimeisellä viikolla maidosta otettiin näyte 4 peräkkäiseltä lypsykerralta. Yhdistetystä näytteestä määritettiin Valion Lapinlahden aluelaboratoriossa rasva-, valkuais-, laktoosi- ja ureapitoisuus (MilkoScan FT6000). Lehmät punnittiin ennen kokeen alkua ja jokaisen jakson lopussa kahtena peräkkäisenä päivänä.

Keruukauden aikana säilö- ja väkirehuista kerättiin päivittäin näytettä rehunpunnitusten yhteydessä analyyseja varten. Dieetin sulavuuden määrittämiseksi (AIA merkkiaineena) 1. blokin lehmiltä kerättiin jokaisen jakson lopussa sontaa viitenä peräkkäisenä päivänä kaksi kertaa päivässä. Lisäksi säilörehujen sulavuus määritettiin pässeillä tehdyssä sulavuuskokeessa kokonaiskeruumenetelmällä. Jokaisen jakson lopussa lehmiltä otettiin verinäyte häntäsuonesta aamulla ennen ruokintaa ja kolmen tunnin kuluttua ruokinnasta. Näytteenottoaikojen yli yhdistetyistä plasmoista määritettiin plasman vapaat rasvahapot (NEFA).

Syönti- ja tuotostiedot laskettiin jokaisen jakson viimeiseltä viikolta. Tulokset testattiin SASin Mixed proseduurilla. Tilastollisessa mallissa oli mukana ruokinta, blokki, jakso sekä blokki*jakso yhdysvaikutus. Eläin oli blokin sisällä satunnaistekijänä. Ruokinnan vaikutusta tutkittiin edelleen jakamalla se kontrasteihin; apilan ensi- ja jälkikasvu, apilan kehitysvaihe, apilan ensi- ja jälkikasvu*kehitysvaihe yhdysvaikutus, kasvilaji sekä kasvilaji*kehitysvaihe yhdysvaikutus. Kokeesta poistettiin yhden lehmän havainnot muista täysin poikkeavan lypsykäyrän vuoksi.

\section{Tulokset ja tulosten tarkastelu}

\section{Rehujen koostumus}

Puna-apilarehut jouduttiin sateisen kesän hankalissa säilöntäolosuhteissa paalaamaan aiottua pienemmässä kuiva-ainepitoisuudessa (taulukko 1). 
Taulukko 1. Säilörehujen raaka-aineen kemiallinen koostumus.

\begin{tabular}{|c|c|c|c|c|c|c|}
\hline & $\mathbf{A A}$ & $\mathbf{A M}$ & $\mathbf{A A J}$ & AMJ & TNA & TNM \\
\hline Niitto (pvm.) & 1.7 .2004 & 14.7 .2004 & 24.8 .2004 & 24.8 .2004 & 15.6 .2004 & 30.6 .2004 \\
\hline Paalaus (pvm.) & 2.7 .2004 & 16.7.2004 & 25.8 .2004 & 25.8 .2004 & 15.6 .2004 & 2.7.2004 \\
\hline Kehitysvaihe & $\begin{array}{r}\text { Kukinta } \\
\text { alussa }\end{array}$ & $\begin{array}{r}\text { Kukinta } \\
\text { loppu- } \\
\text { vaiheessa }\end{array}$ & $\begin{array}{r}\text { Täydessä } \\
\text { kukassa }\end{array}$ & $\begin{array}{r}\text { Kukinta } \\
\text { alussa }\end{array}$ & - & - \\
\hline $\begin{array}{l}\text { Kuiva-aine (KA), g/kg } \\
\text { g/kg KA: }\end{array}$ & 138 & 239 & 214 & 156 & 282 & 242 \\
\hline Tuhka & 99 & 96 & 85 & 108 & 62 & 57 \\
\hline Raakavalk. & 169 & 148 & 148 & 187 & 102 & 84 \\
\hline $\mathrm{NDF}$ & 418 & 447 & 452 & 402 & 590 & 651 \\
\hline $\mathrm{ADF}$ & 243 & 289 & 279 & 226 & 286 & 340 \\
\hline ADL & 25 & 38 & 42 & 23 & 5 & 15 \\
\hline Vesiliuk. hiilihydr. & 72 & 75 & 98 & 81 & 132 & 106 \\
\hline $\mathrm{D}^{-\operatorname{arvo}^{\mathrm{a}}}$ & $650^{\mathrm{e}}$ & $620^{f}$ & $610^{\mathrm{g}}$ & $650^{\mathrm{g}}$ & $700^{c}$ & $620^{\mathrm{d}}$ \\
\hline Purskurikapasiteetti ${ }^{\mathrm{b}}$ & 952 & 938 & 724 & 941 & 462 & 404 \\
\hline \multicolumn{7}{|c|}{$\begin{array}{l}\text { AA=apilan ensikasvu, aik. kehitysvaihe; AM=apilan ensikasvu, myöh. kehitysvaihe; AAJ= AA:n } \\
\text { jälkikasvu; AMJ=AM:n jälkikasvu; TNA=timotei-nurminata, aik. kehitysvaihe; TNM=timotei- } \\
\text { nurminata, myöh. kehitysvaihe; }{ }^{\mathrm{a} N I R, ~ V a l i o n ~ P i t a ̈ j a ̈ m a ̈ e n ~ l a b o r a t o r i o ; ~}{ }^{\mathrm{c}} \text { näyte otettu } 14.6 .{ }^{\mathrm{d}}{ }^{\text {näyte otettu }} \\
\text { 28.6.; }{ }^{\mathrm{e}} \text { näyte otettu 1.7. ; }{ }^{\mathrm{f}} \text { näyte otettu 12.7.; }{ }^{\mathrm{g}} \text { näyte otettu 23.8.; }{ }^{\mathrm{b}} \text { milliekvivalenttia/kgKA }\end{array}$} \\
\hline $\begin{array}{l}\text { aaka-aineen pienen } \\
\text { illarehujen säilönnäll } \\
\text { ukasti sokeria. Se } \\
\text { huissa oli runsaast } \\
\text { konaistypestä oli KT } \\
\text { oihapon määrä rehuis }\end{array}$ & $\begin{array}{l}\text { ainepit } \\
\text { laaduss } \\
\text { an ettà } \\
\text { lonium } \\
\text { 1998) } 1\end{array}$ & $\begin{array}{l}\text { dden ja } \\
\text { tulukko } \\
\text { inän ens }\end{array}$ & $\begin{array}{l}\text { ren pus } \\
\text { Apilarel } \\
\text { vusta m } \\
\text { Mui }\end{array}$ & apasite & vaikutu & $\begin{array}{l}\text { näkyivä } \\
\text { sisälsivä }\end{array}$ \\
\hline
\end{tabular}

Taulukko 2. Säilörehujen kemiallinen koostumus, säilöntälaatu ja rehuarvo.

\begin{tabular}{|c|c|c|c|c|c|c|}
\hline & $\mathbf{A A}$ & $\mathbf{A M}$ & AA.J & AMJ & TNA & TNM \\
\hline KA (korj. $\left.{ }^{a}\right), g / k g$ & 180 & 224 & 251 & 219 & 321 & 277 \\
\hline $\mathrm{pH}$ & 4,05 & 4,30 & 4,22 & 4,31 & 4,25 & 4,11 \\
\hline \multicolumn{7}{|l|}{ g/kg KA: } \\
\hline Tuhka & 87 & 97 & 90 & 102 & 63 & 54 \\
\hline Org.aine & 913 & 903 & 910 & 898 & 937 & 946 \\
\hline Raakavalk. & 166 & 165 & 170 & 193 & 112 & 90 \\
\hline $\mathrm{NDF}$ & 395 & 391 & 373 & 348 & 541 & 601 \\
\hline $\mathrm{ADF}$ & 267 & 285 & 258 & 240 & 288 & 330 \\
\hline ADL & 32 & 41 & 33 & 26 & 9 & 19 \\
\hline INDF & 184 & 203 & 177 & 141 & 82 & 162 \\
\hline Maitohappo & 102 & 106 & 86 & 98 & 42 & 44 \\
\hline Etikkahappo & 27 & 31 & 20 & 29 & 9 & 9 \\
\hline Propionihappo & 0,24 & 0,62 & 0,18 & 0,36 & 0,11 & 0,15 \\
\hline Voihappo & 0,06 & 0,49 & 0,05 & 0,05 & 0,12 & 0,08 \\
\hline Vesiliuk. hiilihydr. & 3 & 12 & 33 & 8 & 102 & 45 \\
\hline Etanoli & 40 & 34 & 37 & 29 & 45 & 75 \\
\hline Liuk.N, g/kg kok.N & 360 & 470 & 372 & 389 & 639 & 625 \\
\hline $\mathrm{NH}_{3}-\mathrm{N}, \mathrm{g} / \mathrm{kg}$ kok.N & 62 & 112 & 68 & 66 & 53 & 90 \\
\hline $\mathrm{OAS}^{\mathrm{b}, \mathrm{c}}, \mathrm{g} / \mathrm{kg} \mathrm{KA}$ & 700 & 655 & 680 & 725 & 743 & 654 \\
\hline D-arvo, g/kg KA & 639 & 591 & 619 & 651 & 696 & 619 \\
\hline $\mathrm{RY} / \mathrm{kg} \mathrm{KA}$ & 0,87 & 0,81 & 0,85 & 0,89 & 0,95 & 0,85 \\
\hline OIV, g/kg KA & 85 & 80 & 83 & 88 & 83 & 74 \\
\hline PVT, g/kg KA & 20 & 27 & 27 & 41 & -29 & -36 \\
\hline Syönti-indeksi & 86 & 75 & 85 & 88 & 103 & 88 \\
\hline
\end{tabular}

${ }^{\mathrm{a}}$ Huida ym. 1986; ${ }^{\mathrm{b}}$ orgaanisen aineen sulavuus; ${ }^{\mathrm{c}}$ määritetty pässeillä tehdyssä sulavuuskokeessa

Puna-apilarehuissa oli enemmän raakavalkuaista ja vähemmän NDF-kuitua kuin heinäkasvisäilörehuissa (taulukko 2). Sulamattoman NDF-kuidun (INDF) pitoisuus oli apilarehuissa 
heinäkasvirehuja suurempi. Ensikasvun korjuun myöhäistäminen lisäsi enemmän heinäkasvien kuin apilan INDF-pitoisuutta (5,3 vs. 1,5 g/pv). Pässikokeessa määritetty säilörehujen orgaanisen aineen sulavuus (OAS) oli suurin varhain korjatussa heinäkasvisäilörehussa (TNA). Kukinnan alkuvaiheessa korjatun apilasäilörehun (AA ja AMJ) sulavuus oli myös hyvä. Apilan orgaanisen aineen sulavuus pieneni korjuuta myöhäistettäessä hitaammin kuin heinäkasvien (3,5 vs. 5,9 g/pv). Apilan ja heinäkasvien orgaanisen aineen sulavuus kertoo sulavuudessa olevista eroista paremmin kuin D-arvo. Koska apila sisältää heinäkasveja enemmän tuhkaa (erityisesti $\mathrm{Ca}$ ja $\mathrm{Mg}$ ), apilan orgaanisen aineen pitoisuus jää pienemmäksi kuin heinäkasvien. Tällöin myös apilan D-arvo jää pienemmäksi kuin heinäkasvien, vaikka orgaanisen aineen sulavuudessa ei olisi suuria eroja.

\section{Syönti ja dieetin sulavuus}

Lehmät söivät eniten varhain korjattua heinäkasvisäilörehua $(\mathrm{p}<0,05)$ (taulukko 3). Useissa kokeissa lehmät ovat kuitenkin syöneet enemmän puna-apilasta (Dewhurst ym. 2003, Bertilsson ja Murphy 2003) tai puna-apilan ja heinäkasvien seoksesta (Heikkilä ym. 1992 ja 1996, Tuori ym. 2000 ja 2002) tehtyä säilörehua kuin heinäkasvisäilörehua. Apilan jälkikasvusta tehtyjä rehuja lehmät söivät enemmän kuin apilan ensikasvusta tehtyjä rehuja ( $<<0,001)$. Bertilssonin ja Murphyn (2003) kokeessa lehmät söivät puna-apilan toisesta sadosta tehtyä rehua keskimäärin $16,3 \mathrm{~kg} \mathrm{KA} / \mathrm{pv}$ ja ensisadosta tehtyä rehua $13 \mathrm{~kg} \mathrm{KA} / \mathrm{pv}$. Heinäkasvien kohdalla tilanne on päinvastainen. Lehmät syövät enemmän ensikasvusta tehtyä säilörehua kuin jälkikasvusta tehtyä rehua (Heikkilä ym. 1998, Kuoppala ym. 2004). Verrattaessa ensikasvusta tehtyjä apilarehuja, lehmät söivät aikaisessa kehitysvaiheessa tehtyä rehua $1,7 \mathrm{~kg} \mathrm{KA} / \mathrm{pv}$ enemmän kuin myöhäisemmässä kehitysvaiheessa tehtyä rehua. Jälkikasvusta tehtyjen rehujen kohdalla tilanne oli päinvastainen, sillä lehmät söivät $1,0 \mathrm{~kg} \mathrm{KA} / \mathrm{pv}$ enemmän samaan aikaan korjattua AAJ-rehua kuin AMJ-rehua sen pienemmästä D-arvosta huolimatta. Tämä yhdysvaikutus apilan ensi- ja jälkikasvun ja kasvuston kehitysvaiheen välillä oli merkitsevä $(\mathrm{p}<0,05)$. Vanhatalon ym. (2005) kokeessa lehmät söivät apilan ensikasvusta myöhäisemmässä kehitysvaiheessa tehtyä rehua $0,7 \mathrm{~kg} \mathrm{KA} / \mathrm{pv}$ enemmän kuin aikaisemmassa kehitysvaiheessa tehtyä rehua. Apilan jälkikasvun korjuuajan vaikutusta lypsylehmien ruokinnassa ei ole aikaisemmin tutkittu. Heinäkasvisäilörehun syöntiin jälkikasvun korjuuajankohdan ei havaittu Kuoppalan ym. (2004) kokeessa vaikuttavan, vaikka rehun D-arvo pienentyikin.

Lehmät söivät tässä kokeessa eri apilasäilörehuja keskimäärin 9,0 - 12,8 kg KA/pv. Varsinkin ensikasvusta tehtyjen apilarehujen vähäinen syönti selittyy pääosin niiden säilönnällisellä laadulla. Lisäksi apilan ensikasvussa oli jonkin verran saunakukkaa, joka on voinut pienentää syöntiä. Syöntiä saattoi vähentää myös apilarehujen pieni kuiva-ainepitoisuus. Koska lehmät söivät kaiken annetun väkirehun, erosi väkirehun osuus kuiva-aineen kokonaissyönnistä ruokintojen välillä merkitsevästi $(\mathrm{p}<0,001)$ (taulukko 3). Raaka-aineen suuremman raakavalkuaispitoisuuden (RV) vuoksi apilarehuja syöneet lehmät saivat enemmän raakavalkuaista kuin heinäkasvirehuja syöneet lehmät $(\mathrm{p}<0,001)$ (taulukko 3). Samoin apilan jälkikasvusta tehtyjä rehuja syöneiden lehmien RV-saanti oli suurempi kuin apilan ensikasvua syöneiden lehmien $(\mathrm{p}<0,001)$. Eniten NDF-kuitua saivat heinäkasvisäilörehuja syöneet lehmät $(\mathrm{p}<0,001)$. Sulamatonta NDF-kuitua saivat eniten apilarehuja syöneet lehmät $(\mathrm{p}<0,001)$. Dieetin kuiva-aineen, orgaanisen aineen ja RV:n sulavuus oli apilaruokinnoilla heinäkasviruokintoja suurempi $(\mathrm{p}<0,001)$ (taulukko 3). Lisäksi kuiva-aineen $(\mathrm{p}<0,05)$, orgaanisen aineen $(p<0,05)$ ja RV:n $(p<0,01)$ sulavuus oli apilan ensikasvua syötettäessä suurempi kuin jälkikasvua syötettäessä. Dieetin NDF-kuitu oli sulavinta apilan ensikasvusta aikaisessa kehitysvaiheessa tehtyä rehua syötettäessä. Samoin kuin Kuoppalan ym. (2005) kokeessa sekä apilan että heinäkasvien NDF:n sulavuus heikkeni rehuntekoa myöhäistettäessä.

\section{Maitotuotos ja maidon koostumus}

Apilasäilörehuja syöneet lehmät lypsivät saman verran tai enemmän kuin aikaisessa kehitysvaiheessa korjattua heinäkasvisäilörehua (TNA) syöneet lehmät pienemmästä säilörehun syönnistä huolimatta (taulukko 4). Myös aikaisemmissa tutkimuksissa maitotuotos on puhdasta puna-apilasäilörehua syötettäessä ollut suurempi kuin heinäkasvisäilörehua syötettäessä vaikka lehmät ovat syöneet apilasäilörehua saman verran (Tuori ym. 2000) tai vähemmän (Tuori ym. 2002, Bertilsson ja Murphy 2003) kuin heinäkasvisäilörehua. Suurempaa maitotuotosta apilasäilörehulla ruokittaessa voi osaksi selittää mikrobivalkuaisen tuotannon tehostumisen ja/tai rehuvalkuaisen pienemmän pötsihajoavuuden vuoksi lisääntynyt ei-ammoniakkitypen (NAN) virtaus ohutsuoleen heinäkasvisäilörehuun verrattuna 
(Vanhatalo ym. 1995). Lisäksi Vanhatalo ym. (2005) havaitsivat, että välttämättömien aminohappojen pitoisuus plasmassa oli apilasäilörehulla ruokittaessa suurempi kuin heinäkasvisäilörehulla ruokittaessa. Apilan jälkikasvusta tehtyä rehua syöneet lehmät lypsivät keskimäärin $1,0 \mathrm{~kg} / \mathrm{pv}$ enemmän kuin ensikasvusta tehtyä rehua syöneet lehmät ( $<<0,05)$. Bertilssonin ja Murphyn (2003) kokeessa maitotuotoksessa ei ollut eroa, vaikka lehmät söivät $3,3 \mathrm{~kg} \mathrm{KA} / \mathrm{pv}$ enemmän puna-apilan jälkikasvusta kuin ensikasvusta tehtyä rehua. Se, oliko apila korjattu aikaisemmassa vai myöhäisemmässä kehitysvaiheessa ei vaikuttanut maitotuotokseen, kuten ei myöskään Vanhatalon ym. (2005) kokeessa. Energiakorjatussa maitotuotoksessa (EKM) ei ollut merkitsevää eroa apila- ja heinäkasviruokintojen välillä.

Maidon rasvapitoisuuteen ja rasvatuotokseen ruokinta ei vaikuttanut tilastollisesti merkitsevästi (taulukko 4). Numeerisesti maidon rasvapitoisuus oli apilasäilörehulla ruokittessa heinäkasvisäilörehuruokintoja pienempi lukuun ottamatta apilan ensikasvusta aikaisessa kehitysvaiheessa tehtyä rehua. Muissa kokeissa maidon rasvapitoisuus on puna-apilasäilörehulla ruokittaessa ollut pienempi (Tuori ym. 2002, Bertilsson ja Murphy 2003, Vanhatalo ym. 2005) tai yhtäsuuri (Vanhatalo ym. 1995, Tuori ym. 2000) kuin heinäkasvisäilörehulla ruokittaessa. Maidon valkuaispitoisuus oli heinäkasviruokinnoilla suurempi kuin apilaruokinnoilla $(\mathrm{p}<0,001)$. Myös Bertilssonin ja Murphyn (2003) sekä Vanhatalon ym. (2005) kokeissa heinäkasvisäilörehua syöneiden lehmien maidon valkuaispitoisuus oli merkitsevästi suurempi kuin apilasäilörehua syöneiden lehmien maidon valkuaispitoisuus. Sen sijaan Tuorin ym. $(2000,2002)$ kokeissa maidon valkuaispitoisuudessa ja valkuaistuotoksessa ei ollut eroa heinäkasvi- ja puna-apilasäilörehun välillä. Apilan jälkikasvusta tehtyjä rehuja syöneiden lehmien maidon valkuaispitoisuus $(p<0,05)$ ja valkuaistuotos $(p<0,01)$ olivat suuremmat kuin apilan ensikasvusta tehtyjä rehuja syöneiden lehmien. Maidon pienempi rasva- ja valkuaispitoisuus apilasäilörehuruokinnoilla heinäkasvisäilörehuihin verrattuna liittyy tässä kokeessa osaksi apilasäilörehujen pidemmälle edenneeseen käymiseen, erityisesti rehujen suureen maitohappopitoisuuteen. Rehussa olevien käymishappojen lisäksi maidon valkuaispitoisuutta pienentää siilossa säilönnän aikana tapahtuva valkuaisen hajoaminen (Huhtanen ym. 2003).

Apilasäilörehu lisäsi maidon ureapitoisuutta heinäkasvisäilörehuun verrattuna $(p<0,001)$ (taulukko 4). Samoin runsaammin valkuaista sisältänyt, aikaisessa kehitysvaiheessa korjattu apilasäilörehu (AA ja AMJ) lisäsi maidon ureapitoisuutta enemmän kuin myöhäisemmässä kehitysvaiheessa korjattu rehu (AM ja AAJ) $(\mathrm{p}<0,05)$. Tärkein maidon ureapitoisuuteen vaikuttava tekijä on dieetin RV-pitoisuus (Nousiainen ym. 2004). Sen noustessa pötsimikrobien typen hyväksikäyttö heikkenee. Rehuvalkuaisen muuntaminen maidon valkuaiseksi oli tehokkainta heinäkasviruokinnoilla ja heikointa apilan jälkikasvusta tehtyjä rehuja syötettäessä $(p<0,001)$. Apilan kehitysvaihe ei vaikuttanut rehuvalkuaisen muuntamiseen maitovalkuaiseksi. Energiakorjatun maitotuotoksen suhde syötyyn kuiva-ainemäärään oli apilaruokinnoista suurin apilan ensikasvua syöneillä lehmillä ja heikoin aikaisin korjattua heinäkasvisäilörehua syöneillä lehmillä $(p<0,01)$. Apilaruokinnoilla, lukuun ottamatta aikaisin korjatun apilan jälkikasvusta tehtyä rehua, lehmät menettivät jonkin verran painoaan $(\mathrm{p}<0,10)$ (taulukko 4). Rasvakudoksen mobilisaatiota kuvaava plasman NEFA-pitoisuus oli kuitenkin matala (0,186 (AA), 0,232 (AM), 0,199 (AAJ), 0,209 (AMJ), 0,198 (TNA), 0,208 (TNM) mmol/l) eikä siinä ollut eroa ruokintojen välillä, joten elopainon muutos apilaruokinnoilla liittyy osaksi pienempään säilörehun syöntiin.

\section{Johtopäätökset}

Lehmät söivät apilasäilörehuja vähemmän kuin aikaisessa kehitysvaiheessa tehtyä heinäkasvisäilörehua. Syönnin vertailua vaikeuttivat kuitenkin hankalien säilöntäolosuhteiden vuoksi apila- ja heinäkasvisäilörehujen välillä säilönnällisessä laadussa ja kuiva-ainepitoisuudessa olleet erot. Kaikki koerehut olivat hyvin säilyneitä, mutta apilarehut olivat pidemmälle käyneitä kuin heinäkasvirehut. Eri apilarehujen välillä säilöntälaadussa ei juuri ollut eroa, mutta lehmät söivät enemmän jälki- kuin ensikasvusta tehtyjä rehuja. Apilan ensikasvusta tehdyn rehun syönti ei sulavuuden pienentyessä vähentynyt yhtä selvästi kuin heinäkasvirehun syönti. Apilan jälkikasvurehuja verrattaessa syönti puolestaan lisääntyi sulavuuden pienentymisestä huolimatta. Apilarehulla sekä ensi- että jälkikasvun korjuuajan vaikutus syöntiin näyttääkin poikkeavan heinäkasvisäilörehusta. Pienemmästä säilörehun syönnistä huolimatta apilarehuja saaneet lehmät lypsivät saman verran tai enemmän kuin hyvälaatuista heinäkasvirehua saaneet lehmät. Ero ei selity 
rasvakudoksen mobilisaatiolla, sillä plasman NEFA-pitoisuudessa ei ollut eroa ruokintojen välillä. Mahdollisesti pötsin mikrobivalkuaissynteesi oli tehokkaampaa apilasäilörehulla ruokittaessa. Pienempi maidon valkuaispitoisuus apilarehuja syötettäessä voi osittain selittyä eroilla rehujen käymislaadussa.

Runsaasti apilaa sisältävällä säilörehulla ruokittaessa koko rehuannoksen raakavalkuaispitoisuus saattaa nousta typen hyväksikäytön kannalta liian suureksi, mikä näkyy mm. maidon kohonneena ureapitoisuutena. Jos väkirehun määrä ruokinnassa on pieni, säilörehun ravitsemuksellisen ja säilönnällisen laadun merkitys korostuu, jotta lehmän energian tarve saadaan täytetyksi.

\section{Kirjallisuus}

Bertilsson, J. \& Murphy, M. 2003. Effects of feeding clover silages on feed intake, milk production and digestion in dairy cows. Grass and Forage Sci. 58: 309-322.

Dewhurst, R.J., Fisher, W.J., Tweed, J.K.S. \& Wilkins, R.J. 2003. Comparison of legume silages for milk production. 1. Production responses with different levels of concentrate. J. of Dairy Sci. 86: 2598-2611.

Heikkilä, T., Toivonen, V. \& Mela, T. 1992. Comparison of red clover-grass silage with grass silage for milk production. Proc. $14^{\text {th }}$ Gen. Meet. Eur. Grassl. Fed. Lahti, Finland. p. 388-391.

Heikkilä, T., Toivonen, V. \& Mela, T. 1996. Effects of red clover-grass, grass and annual ryegrass silages with two concetrate protein levels on milk production. In: Parente, G., Frame, J. \& Orsi, S. (eds.). Proc. $16^{\text {th }}$ Gen. Meet. Eur. Grassl. Fed. Grado, Italy Grassl. Sci. in Europe 1: 447-450.

Heikkilä, T., Toivonen, V. \& Huhtanen, P. 1998. Effect of spring and autumn silage, protein and concentrate level on milk production. In: Nagy, G. \& Petö, K. (eds.). Proc of the $17^{\text {th }}$ Gen. Meet. of the Eur. Grassl. Fed. "Ecological aspects of grassland management". p 717-721.

Huhtanen, P., Nousiainen, J.I., Khalili, H., Jaakkola, S. \& Heikkilä, T. 2003. Relationships between silage fermentation characteristics and milk production parameters: analyses of literature data. Livest. Prod. Sci. 81: 57-73.

Huida, L., Väätäinen, H. \& Lampila, M. 1986. Comparison of dry matter contents in grass silages as determined by oven drying and gas chromatographic water analyses. Annales Agriculturae Fenniae 25: 215-230. KTTK. 1998. Kasvintuotannon tarkastuskeskus/Maatalouskemian osasto. Tiedote 7.

Kuoppala, K., Ahvenjärvi, S., Rinne, M. \& Vanhatalo, A. 2005. NDF digestion in dairy cows fed grass or red clover silages cut at two stages of growth. In: Park, P.S. \& Stronge, M.D. (eds.) "Silage production and utilisation". Proceedings of the XIVth International Silage Conference, a satellite workshop of the XXth International Grassland Congress, July 2005, Belfast, Northern Ireland. p. 164.

Kuoppala, K., Rinne, M., Nousiainen, J. \& Huhtanen, P. 2004. Säilörehun ensi- ja jälkasvun korjuuajan sekä väkirehutäydennyksen vaikutus lypsylehmien maidontuotantoon. Julkaisussa: MaataloustieteenPäivät 2004 [verkkojulkaisu]. Suomen Maataloustieteellisen Seuran tiedote no 19. Toim. Anneli Hopponen ja Marketta Rinne.Viitattu [22.11.2005]. Julkaistu 5.1.2004. Saatavilla $\quad$ Internetissä: http://www.agronet.fi/maataloustieteellinenseura /julkaisut/esi04/ti54.pdf. ISBN 951-9041-47-8.

Nousiainen, J., Shingfield, K.J. \& Huhtanen, P. 2004. Evaluation of milk urea nitrogen as a diagnostic of protein feeding. J. of Dairy Sci. 87: 386-398.

Sjaunja, L.O., Baerve, L., Junkkarinen, L., Pedersen, J., Setälä, J. 1990. A Nordic proposal for energy corrected milk (ECM) formula. In: 27th Session International Committee of Recording and Productivity of Milk Animal, Paris, France. p. 156-157.

Tuori, M., Villikka, U., Huuskonen, A. \& Syrjälä-Qvist, L. 2000. Puna-apila- ja vuohenhernesäilörehut uhtaana sekä nurmisäilörehun kanssa seoksena lypsylehmien ruokinnassa. In: Rinne, M. (toim.). Maataloustieteen Päivät 2000. Kotieläintiede. Maaseutukeskusten Liiton julkaisutja nro 952. p. 134-137.

Tuori, M., Syrjälä-Qvist, L. \& Jansson, S. 2002. Puna-apila- ja nurminatasäilörehu eri suhteissa lypsylehmien ruokinnassa. In: Rinne, M. (toim.). Maataloustieteen Päivät 2002. Kotieläintiede. Maaseutukeskusten Liiton julkaisuja nro 977. p. 143-146.

Vanhatalo, A. Heikkilä, T. \& Gäddnäs, T. 1995. Puna-apilapitoinen säilörehu lypsylehmien ruokinnassa: vaikutus valkuaissynteesiin, pötsifermentaatioon ja maidontuotantoon heinäsäilörehuun verrattuna. In: Jokela, M. (toim.). Kotieläintieteen Päivät 1995. Maaseutukeskusten Liiton julkaisuja nro 888. p. 190-193.

Vanhatalo, A., Kuoppala, K., Ahvenjärvi, S. \& Rinne, M. 2005. Responses to grass or red clover silages cut at two stages of growth in dairy cows. In: Park, P.S. \& Stronge, M.D. (eds.) "Silage production and utilisation". Proceedings of the XIVth International Silage Conference, a satellite workshop of the XXth International Grassland Congress, July 2005, Belfast, Northern Ireland. p. 139. 
Taulukko 3. Rehun syönti, ravintoaineiden saanti ja dieetin sulavuus.

\begin{tabular}{|c|c|c|c|c|c|c|c|c|c|c|c|c|c|}
\hline & \multirow[b]{2}{*}{$\begin{array}{c}\mathbf{A A} \\
(n=7)\end{array}$} & \multirow[b]{2}{*}{$\begin{array}{c}\mathbf{A M} \\
(\mathbf{n}=7)\end{array}$} & \multirow[b]{2}{*}{$\begin{array}{c}\text { AAJ } \\
(\mathbf{n}=8)\end{array}$} & \multirow[b]{2}{*}{$\begin{array}{l}\mathbf{A M J} \\
(n=7)\end{array}$} & \multirow[b]{2}{*}{$\begin{array}{l}\text { TNA } \\
(n=8)\end{array}$} & \multirow[b]{2}{*}{$\begin{array}{l}\text { TNM } \\
(n=7)\end{array}$} & \multirow[b]{2}{*}{ SEM } & \multirow[b]{2}{*}{$\begin{array}{l}\text { Ruo- } \\
\text { kinta }\end{array}$} & \multicolumn{5}{|c|}{ Tilastollinen merkitsevyys } \\
\hline & & & & & & & & & $\begin{array}{c}\text { Apila ensi- } \\
\text { kasvu vs. } \\
\text { jälkikasvu }\end{array}$ & $\begin{array}{l}\text { Apila aik. } \\
\text { vs. apila } \\
\text { myöh. }\end{array}$ & $\begin{array}{c}\text { Apila } \\
\text { yhdys- } \\
\text { vaik. }\end{array}$ & $\begin{array}{l}\text { Apila vs. } \\
\text { nurmi }\end{array}$ & $\begin{array}{c}\text { Kasvilajix } \\
\text { kehitys- } \\
\text { vaihe }\end{array}$ \\
\hline Syönti: & & & & & & & & & & & & & \\
\hline Säilörehu, kg KA/pv & 10,7 & 9,0 & 12,8 & 11,8 & 14,3 & 8,3 & 0,67 & $* * *$ & $* * *$ & & $*$ & $*$ & $* *$ \\
\hline Väkirehu, kgKA/pv ${ }^{\mathrm{a}}$ & 8,3 & 8,3 & 8,3 & 8,3 & 8,3 & 8,3 & & & & & & & \\
\hline Yht. kg KA/pv ${ }^{b}$ & 19,1 & 17,4 & 21,3 & 20,2 & 23,0 & 17,0 & 0,67 & $* * *$ & $* * *$ & & $*$ & $* *$ & $* *$ \\
\hline Vr.-osuus, g/kg KA & 461 & 507 & 410 & 433 & 379 & 522 & 16,7 & $* * *$ & $* * *$ & & $*$ & $*$ & $* *$ \\
\hline Org. aine, $\mathrm{kg} / \mathrm{pv}$ & 17,8 & 16,1 & 19,7 & 18,6 & 21,4 & 15,9 & 0,62 & $* * *$ & $* * *$ & & $*$ & $* *$ & $* *$ \\
\hline Raakavalk., g/pv & 3378 & 3077 & 3782 & 3865 & 3212 & 2348 & 110,4 & $* * *$ & $* * *$ & o & & $* * *$ & $* *$ \\
\hline NDF, $g / p v$ & 6330 & 5605 & 6849 & 6216 & 9815 & 7094 & 284,7 & $* * *$ & $*$ & & $*$ & $* * *$ & $* * *$ \\
\hline INDF, $\mathrm{g} / \mathrm{pv}$ & 2767 & 2629 & 3086 & 2472 & 1995 & 2169 & 108,3 & $* * *$ & & $*$ & $* * *$ & $* * *$ & \\
\hline Sulavuus, g/kg: & $(n=3)$ & $(n=3)$ & $(n=4)$ & $(n=3)$ & $(n=4)$ & $(n=3)$ & & & & & & & \\
\hline Kuiva-aine & 763 & 711 & 687 & 685 & 672 & 589 & 21,1 & $* *$ & $*$ & & & $* * *$ & \\
\hline Org. aine & 773 & 720 & 696 & 697 & 687 & 607 & 20,8 & $* *$ & $*$ & & & $* * *$ & \\
\hline Raakavalk. & 785 & 732 & 689 & 685 & 634 & 605 & 24,4 & $* *$ & $* *$ & & & $* * *$ & \\
\hline NDF & 602 & 487 & 478 & 496 & 569 & 412 & 32,0 & $*$ & o & * & & o & \\
\hline
\end{tabular}

Taulukko 4. Maitotuotos, maidon koostumus ja rehun hyväksikäyttö.

\begin{tabular}{|c|c|c|c|c|c|c|c|c|c|c|c|c|c|}
\hline & \multirow[b]{2}{*}{$\begin{array}{c}\mathbf{A A} \\
(n=7)\end{array}$} & \multirow[b]{2}{*}{$\begin{array}{c}\mathbf{A M} \\
(\mathbf{n}=7)\end{array}$} & \multirow[b]{2}{*}{$\begin{array}{c}\mathbf{A A J} \\
(\mathbf{n}=\mathbf{8})\end{array}$} & \multirow[b]{2}{*}{$\begin{array}{l}\text { AMJ } \\
(\mathbf{n}=7)\end{array}$} & \multirow[b]{2}{*}{$\begin{array}{r}\text { TNA } \\
(n=8)\end{array}$} & \multirow[b]{2}{*}{$\begin{array}{l}\text { TNM } \\
(\mathbf{n}=7)\end{array}$} & \multirow[b]{2}{*}{ SEM } & \multicolumn{6}{|c|}{ Tilastollinen merkitsevyys } \\
\hline & & & & & & & & $\begin{array}{l}\text { Ruo- } \\
\text { kinta }\end{array}$ & $\begin{array}{c}\text { Apila ensi- } \\
\text { kasvu vs. } \\
\text { jälkikasvu }\end{array}$ & $\begin{array}{l}\text { Apila aik. } \\
\text { vs. apila } \\
\text { myöh. }\end{array}$ & $\begin{array}{c}\text { Apila } \\
\text { yhdys- } \\
\text { vaik. }\end{array}$ & $\begin{array}{c}\text { Apila vs. } \\
\text { nurmi }\end{array}$ & $\begin{array}{c}\text { Kasvilajix } \\
\text { kehitys- } \\
\text { vaihe } \\
\end{array}$ \\
\hline Maito, kg/pv & 28,3 & 28,4 & 29,1 & 29,7 & 28,6 & 25,5 & 1,05 & $* * *$ & $*$ & & & $*$ & $* *$ \\
\hline $\mathrm{EKM}, \mathrm{kg} / \mathrm{pv}^{\mathrm{a}}$ & 29,2 & 28,6 & 29,7 & 30,1 & 29,9 & 26,6 & 1,11 & $* *$ & & & & & $*$ \\
\hline Rasva, g/pv & 1236 & 1167 & 1207 & 1232 & 1245 & 1116 & 57,7 & & & & & & \\
\hline Valkuainen, g/pv & 943 & 955 & 1004 & 1006 & 995 & 883 & 30,8 & $* *$ & $* *$ & & & & $* *$ \\
\hline Laktoosi, g/pv & 1276 & 1300 & 1328 & 1358 & 1299 & 1149 & 48,7 & $* * *$ & $*$ & & & $*$ & $* *$ \\
\hline Rasva, g/kg & 44,2 & 41,2 & 42,2 & 41,6 & 43,9 & 44,3 & 1,56 & & & & & & \\
\hline Valkuainen, $\mathrm{g} / \mathrm{kg}$ & 33,6 & 33,9 & 34,8 & 34,0 & 35,1 & 34,9 & 0,62 & $* *$ & $*$ & o & & $* * *$ & \\
\hline Laktoosi, g/kg & 45,0 & 45,9 & 45,7 & 45,7 & 45,4 & 44,9 & 0,43 & $*$ & & o & $\mathrm{o}$ & & $* *$ \\
\hline Urea, $\mathrm{mg} / 100 \mathrm{ml}$ & 38 & 37 & 35 & 42 & 25 & 31 & 2,1 & $* * *$ & & $*$ & & $* * *$ & o \\
\hline Maidon N/rehun N & 27,4 & 30,7 & 26,1 & 25,6 & 30,5 & 37,0 & 1,43 & $* * *$ & $*$ & & & $* * *$ & \\
\hline EKM kg/kg KA & 1,55 & 1,66 & 1,40 & 1,49 & 1,30 & 1,57 & 0,079 & $* *$ & $*$ & & & $*$ & \\
\hline Elop. muutos, kg/pv & $-0,297$ & $-0,216$ & 0,231 & $-0,158$ & 0,523 & $-0,131$ & 0,2263 & $\mathrm{o}$ & & & & $\mathrm{o}$ & \\
\hline
\end{tabular}

${ }^{a}$ Sjaunja ym. (1990); Tilastollinen merkitsevyys ${ }^{* * *}=\mathrm{p}<0.001,{ }^{* *}=\mathrm{p}<0.01,{ }^{*}=\mathrm{p}<0.05, \mathrm{o}=\mathrm{p}<0.10$ 